\title{
CO-OPTING HUMAN SECURITY AND DEDUCTIONS FOR SECURITY POLICY-MAKING IN GHANA
}

\author{
Philip K. Attuquayefio \\ Legon Centre for International Affairs \& Diplomacy (LECIAD) \\ University of Ghana, Legon \\ Accra, Ghana \\ Email:pattuquayefio@ug.edu.gh \\ doi:10.4314/gjds.v9i1.7
}

\begin{abstract}
Popularized in development and security parlance by the Human Development Report of 1994, human security emphasizes prevention and protection of people from critical and pervasive threats that violently disrupt lives. Its conceptual basis derives from the inadequacy of the statecentric conception of security to comprehensively address threats to people, particularly those of a non-military nature. Despite agreement over the importance of making the individual the referent object of security, specific threats that should be considered under human security are inconclusive. Additionally, critics argue that human security merely echoes aspects of human rights and development studies and as such, has nothing new to offer. These issues continue to hamper efforts to co-opt the concept into the mainstream of security dialogue and policy-making. Through content analysis of secondary data, this article presents obstructions to the co-optation of human security into the mainstream of the security dialogue and policy-making, and juxtaposes it against trends that appear to be promoting its integration in relevant fields of endeavour. It argues that far from being an abstract idea, human security meets a tangible need. Using Ghana as a case study, the article hints at possible implications of the co-optation of human security on security policy-making in Ghana.
\end{abstract}

Keywords: Human Security, Protection, Empowerment, Threats, National Security

\section{INTRODUCTION}

The post-Cold War era is witnessing unprecedented threats from issues hitherto perceived as falling outside the scope of security but which are increasingly challenging the very survival of countries and the people living within these countries. Consequently, climate change, water shortage, health challenges such as the Human Immunodeficiency Virus (HIV), and the causes and effects of chronic and persistent poverty and lack of effective governance are gaining some prominence in discussions on security and threat perception (Gamba, 1997).

With the recognition of the above threats, the apparent, and in some cases obvious inability of the state to offer adequate protection to citizens invariably point to some sort of dysfunction within the traditional state-centric security system. It therefore becomes essential for any meaningful discussion on security to go beyond the state-centric view of security, to the security of the people living within the state - their human security. This strengthens the need for an alternative paradigm to understanding emerging threats to the security of people and an appropriate framework for considering such challenges. In this regard, human security emphasizes threats posed by factors such as hunger and disease as well as others that violently disrupt the lives of people. Thus, while conceding to the relevance of state-centric security, advocates of human security redefine security to ensure that other threats to the survival of the people within the state are given prominence. 
Despite the agreement over the importance of making people the referent object of security, specific threats to consider under human security remains inconclusive. This, it is strongly suggested, is the result of the lack of consensus on the definition and scope of human security. This lack of consensus, in addition to criticisms against the novelty and necessity of the components of human security is persistently challenging attempts at co-opting the concept of human security.

Through content analysis of secondary data, this article traces the historical development of human security. It also examines the challenges and prospects of co-opting the concept into the mainstream of security dialogue and policy making and the possible implications on security policy-making in Ghana.

\section{DEVELOPMENT AND NATURE OF HUMAN SECURITY}

\section{Development of Human Security}

Historically, focusing on the individual as the referent object of rights and liberties is not novel. Owen (2004:1) suggests that some of the principles underlying Human Security are rudimentary reflections of the liberalist theologies of Montesquieu, Rousseau and Condorcet. 6 Contemporarily, a notable precursor to the Human Development Report was the Independent Commission on Disarmament and Security Issues (Palme Commission) formed in the autumn of 1980 (Zgüç, 2007). In fact, the Palme Commission suggested that conceptions of security must move from a militaristic model to a more holistic model. However, it failed to make reference to the "human" aspect. This notwithstanding, considering that the Commission operated within the Cold War context that so strengthened the realist perception of security, the precursory value of the Palme Commission Report to the origin of human security is noteworthy.

Similar to the Palme Commission report, the 1993 Human Development Report (HDR) of the United Nations Development Programme (UNDP) also advocated for a modification of the perception of security from an exclusive stress on national security to a much greater stress on people's security; from security through armaments to security through human development, from territorial security to food, employment and environmental security (UNDP, 1993).

Succeeding the 1993 HDR was the 1994 HDR that is so often linked to the evolution of human security. Hendricks ( 2007: IV) highlights the essence of the 1994 Report by noting that though the idea of the need to broaden security had been on the margins of security discourse, the 1994 Report gave "coherent and systematic" expression to those ideas and named the concept Human Security. Therefore, the 1994 HDR is not just popular for its explicit use of the concept Human Security, but also, its contribution towards a greater understanding of the concept through offering key explanations on various components of human security. Perhaps, in anticipation of the definitional challenges, the 1994 HDR identified seven categories under which human security may be considered. These categories, which are identified in some detail in the next section, include economic security, food security, health security, environmental security, personal security and political security (UNDP, 1994: 25).

Subsequent HDRs, since 1994, have consistently advocated human security by stressing both its quantitative and qualitative aspects (Thomas \& Wilkin, 1999). However, a more persuasive rendition of human security, that appeared to have reinforced the 1994 HDR, came in the form of the Millennium Report of the Secretary General of the United Nations in 2000 (United

\footnotetext{
${ }^{6}$ Operating under the banner of Enlightenment in $18^{\text {th }}$ Century in Europe, these theorists generally questioned the absolutism of the church and the prevailing monarchs of the time by stressing the fundamentals of individual liberty.
} 
Nations, 2000). The Report contained chapters on 'freedom from fear' and 'freedom from want'. These two ideas characterized as the Security and Development agenda respectively, reestablished the security-development nexus and in the process reaffirmed the concept of human security.

The combined effect of the Human Development and Millennium Report undeniably received a further boost in 2001 with the setting up of the Commission on Human Security (CHS) in 2003. The CHS published Human Security Now, a survey of findings of contemporary understanding and approaches to Human Security in which it noted that "Human Security is concerned with safeguarding and expanding people's vital freedoms. It requires both shielding people from acute threats and empowering people to take charge of their lives" (CHS, 2003: IV). The CHS thus established "Empowerment" as the complementary arm of 'Protection' insofar as ensuring human security is concerned.

\section{Defining Human Security}

The search for a definition of human security justifiably starts from the contemporary debut of the concept in the 1994 HDR of the UNDP. The 1994 HDR affirms that human security has two main facets - the safety from chronic threats such as hunger, disease and repression, and protection from sudden and hurtful disruptions in the patterns of daily life such as in jobs, homes or communities. Based on this conception, the Report suggested seven categories of threats to human security (UNDP, 1994). The first of this is Economic Security, which is defined as a guarantee of basic income for individuals, usually from productive work or from a public finance system. The Report also identifies Food Security and Health Security. The former is defined as an assurance of physical and economic access to basic food at all times, while the latter is defined as, a guarantee of a minimum protection from diseases and lifestyles that are detrimental to the health of people. The Report also identifies Environmental Security as protection from the effects of deterioration of the natural environment while Personal Security, is seen as the protection of people from physical violence. The sixth and seventh categories from the 1994 HDR are Community and Political Security. Community Security is defined as protection of people from the loss of traditional relationships values and from sectarian and ethnic violence, while Political Security is identified as an assurance that people live in a society that honors their basic human rights among others.

Following the above, a number of generally helpful definitions have emerged. The Commission for Human Security (CHS2003:4) for instance describes the concept as protection of "the vital core of all human lives in ways that enhance freedoms and human fulfillment, Human Security means protecting fundamental freedom -freedoms that are the essence of life. It means protecting people from critical (severe) and pervasive (widespread) threats and situations." A critical reading of the Commission's usage of the phrase 'vital core' suggests a reference to the very existence of human kind, sometimes described as the essence of life.

One common element that is reinforced by the various definitions is the consideration of security in people-centered terms. In spite of this, there are variances that have a bearing on the methodological nuances and by inference, the measurement of human security as well as its analytical relevance within a variety of contexts. A typical implication of the differences is the contention over the nature of threats to the individual on which human security should be focused. Issuant to this, two schools have emerged. These have been widely categorized as the 'narrow' and' broad' definitions (Krause, 1998; Thakur, 2000)

The narrow definition limits human security to the absence of violence or what has been termed 'freedom from fear '(Krause, 1998; Mack, 2004). This approach seeks to limit the practice of human security to protecting individuals from threats that may come from issues such as the drug trade, landmines, ethnic discord, state failure, and trafficking in small arms (Collier, 1998). 
By so doing, the definition restricts the parameters of human security to violent threats against the individual while recognizing that these violent threats are strongly associated with poverty, lack of state capacity and other forms of inequities. The narrow definition has been portrayed as offering a more realistic and manageable approach towards human security, by presenting the opportunity for immediate intervention, rather than the long term planning for sustainable development.

The broad definition of human security, on the other hand, goes beyond the narrow approach described above to include 'freedom from want' (Thakur, 2000)). Drawing largely from the 1994 HDR of the UNDP as well as the report of the Commission on Human Security (2003), this school contends that chronic hunger, disease, and repression as well as sudden disasters, offer sufficient threats to the security of individuals. It, therefore, expands the focus beyond violence with emphasis on development and security goals. It further advocates that a holistic approach to achieving human security must recognize such broad threats as inseparable concepts in addressing the root of human insecurity (Collier, 1999).

In an effort to find a common ground between the two schools, Owen (2004:382) notes that a 'hybrid' human security definition "must recognise that there is no difference between deaths from floods, communicable disease, or war as all preventable harms could potentially become threats to human security." Owen's (2004) contribution lies in emphasizing a clear threshold, a kind of boundary within which threats to human security can be assessed. This is first achieved through highlighting the Commission on Human Security's (2003) critical and pervasive criteria in describing what constitutes a threat to Human Security. As a result, the numerous potential threats to Human Security, that make the concept analytically unattractive, are expected to be substantially pruned down (Owen, 2004:382). His endeavour seems to have yielded a permutation of key aspects of the two main schools. The outcome is human security defined as protection of the vital core of all human lives from critical and pervasive environmental, economic, food, and health, personal and political threats. This is useful for the academic and practical treatment of human security.

\section{Essence of Human Security}

Appreciating the essence of Human security necessarily demands an understanding of the traditional state-centric notion of security. Under this notion, the state is considered and, indeed, acts as the primary provider of security as well as the referent object of security. According to Weber (1919), this arrangement grants the government of states, legitimate monopoly over violence within the territorial boundaries of the state and in turn assures the people living within such boundaries of the security of their persons.

The traditional security concerns that set the state as the referent object of security arose from the Treaty of Westphalia that created the modern state system in the 17th Century. As a result, the international system was conceptualized as a platform for the interaction of sovereign States, with no governing authority to enforce laws or some conception of international justice (Wilkin 1999). The implication of this anarchic arrangement was that States, acting as rational entities, had to necessarily operate a self-help system to ward of perceived or actual threats from other states. Thus, the international system became the realm of survival in which threats were deemed to be targeted at states and not to the people within the state (Fell 2006). Further, the threats were deemed to be of a military nature, targeting the territorial integrity, national independence or sovereignty of States (Viotti \& Kauppi, 1999). Guaranteeing security of states (national security) against such threats therefore necessitated corresponding military-based defense frameworks. These were identified as the predominant security concerns of States (Waltz, 1979; Buzan, 1983). 
Essentially, therefore, the traditional state-centric notion of security is premised on three foundations. The first is that the state is the primary provider of security to individuals living within it. Second, threats are perceived to be directed to the state and not to the people within the state. The presumptive consequences being that, if the state is secure, then those who live within it are secure. Third, the threats directed to the state are of a military nature.

The utility of the three foundations above has been challenged in the post-Cold War era. The first challenge has been with the nature of threats, previously identified from the realist point of view as military in nature. Following the end of the Cold War, and the brief interregnum in power politics (till the September 11, 2001 terrorist attacks on the US), attention was focused on issues that were not novel, but whose effects on the security of people and states were recognized as real and potent (UNDP, 1993; UNDP 1994; Buzan, Wæver \& De Wilde, 1997). Threats posed by the social and economic consequences of a depleting ozone layer and the threat of HIV for instance, questioned the rationale for placing all premium on threats of a military nature.

Second, considering that the threats as identified above were transnational in nature and directly affected people living within states, the conventional wisdom of considering states as objects of threats has been rendered problematic. It has therefore become more than apparent that a secure state does not necessarily guarantee the security of the individuals and communities within the state (Human Security Report, 2005).

A third challenge to the foundations of the traditional notion of security has been with regard to the provider of security. Although the state is legally the primary provider of security, in practice, the various governments or regimes are the animate representatives that ensure that rights and responsibilities of the state are actualized. The first aspect of this challenge, therefore, emerged from the threat posed by the de jure providers of security to the people they were supposed to secure. In cases such as in Rwanda and Sierra Leone, for instance, the state, rather than ensuring the security of individuals and communities living within the state, became the potential and actual threats to the security of individuals and communities within its territory (Prunier, 1995). A further challenge to the state's ability to provide security to their citizens emerged from the weakening of the military capability of a number of states, particularly in Africa, in the post-Cold War era. This was due to the decline in the military relevance of such states following the end to the numerous proxy wars that characterized Cold War politics. As a result, a number of states have themselves been rendered susceptible to the activities of violent sub-national groups (Howe, 2001).

In providing a remedy to the challenges identified above, human security seeks to reflect security from critical and pervasive threats posed by factors such as hunger and disease as well as other factors that violently disrupt the lives of people living within states. Such factors may be economic, health related, environmental or even food based (Annan, 2000). Thus, human security, while recognizing the relevance of territorial security, argues for threats to individuals living within the state to be granted priority. It also recognizes threats and conditions that have not always been classified as threats to state security. Finally, it expands the range of actors providing security beyond the state.

Notwithstanding the essence of human security, its complete co-optation into security discourse is challenged on several fronts. The next section examines challenges and prospects for coopting human security. 


\section{HUMAN SECURITY AS AN EMERGING SECURITY PARADIGM}

\section{Challenges and Prospects for Co-optation}

Two main challenges confront the co-optation of human security. The first has to do with the Realist perspective of security and its potential in rendering redundant, the human security drive. This is based on the argument that although the state-centric notion has the state as the referent object of security, the ultimate goal of protecting the State is to ensure that the people living within the territory are safe. Individual security concerns are, therefore, deemed to be included in the traditional concept of security (Buzan, Wæver \& De Wilde, 1998). As a consequence to this, Buzan (2001) notes that while the state may pose a threat to the security of people living within its territory; the security of such people cannot be assured outside the state protection. Du Pisani (1992:4) hence alludes that "it is only academic to conceive of security and development without strong, legitimate states." This explains why in countries such as Rwanda, Liberia, Cote D'Ivoire and Sierra Leone, for instance, the state remains a key player in the provision of security to its citizens despite the role it played in the abuse of its citizens during their respective civil wars. Similarly, from a Ghanaian perspectives, it can be argued that although at some point in history, the state through its agents appeared to have reneged on its primary role of protecting Ghanaians (particularly during the various periods of political instability), the state maintains its primary role in ensuring the security of Ghanaians.

The suggestion that the security of individuals cannot be assured outside state protection appear to be flawed by what appears to be the globalization of governance standards in the post-Cold War era. At the backdrop of these governance standards are purposeful moves towards an acceptable human rights standard of what Lynch (2001:91) describes as "intrusive human rights norms" that seem to guide national leaders on the importance of upholding human rights. Ensuing from these norms, the orthodoxy of the principle of "territorial integrity," as situated within the straitjacket of the concept of state sovereignty, behind which state leaders hide to perpetuate abuses against their citizens, is rapidly giving way to an emerging concept of responsible governance or the Responsibility to Protect (Attuquayefio, 2008). The effect of the realist arguments insofar as co-opting human security is concerned is as a result subdued.

A second challenge to the co-optation of human security has to do with questions about its analytical efficacy or the lack thereof. Buzan (2004), for instance, portrays human security as a reductionist, idealistic notion that adds little analytical value. Krause (2007) also alludes that the broad approach to understanding security is tantamount to merely creating a shopping list of bad things that can happen and therefore, robs the approach of analytical utility. However, in defense of human security, I argue that advocating for a change in the referent object of security from the state to the individual, must necessarily consider all the interrelated threats to the security of the individual be they military, physical or otherwise. In fact, within the context of security, it may seem paradoxical to concede inter-relatedness of certain variables, and yet limit policy to just parts rather than the whole on account of it being broad.

Notwithstanding the above, other developments suggest that the concept (as used analytically and descriptively) is receiving appreciable interest in relevant fields of endeavour. Prime among this is the number of states and international organizations formulating policies around the concept of human security. At the vanguard of these attempts is Canada. Although it acknowledges the 1994 HDR of the UNDP as the source of the specific phrase - human security, it critiques the report for focusing too much on threats associated with underdevelopment and ignoring human insecurity resulting from violent conflict. Thus, within the general context of human security, Canada focuses Protection of civilians; peace support operations; conflict prevention; governance and accountability; as well as public safety (Edson, 2001). 
Guided by human security, Canada has played pronounced roles in a number of international activities. This includes the Ottawa Process which led to the signing by 122 countries of the "Convention on the Prohibition, Use, Stockpiling, Production and Transfer of Anti-Personnel Landmines and their Destruction" in December 1997; the processes towards the creation of the International Criminal Court; the Kimberley Process on trade in diamonds from conflict zones; and the launching of the International Commission on State Sovereignty and Intervention with its landmark report, Responsibility to Protect, published in September 2000 by the Canadian Department of Foreign Affairs and International Trade. The Responsibility to protect report addressed some of the criticisms of the interventionist elements of its "freedom from fear" approach (Tadjbakhsh, 2005:22).

Japan also observes human security, but does so from a different perspective. It notes that while the Canadian perspective is essential, it is necessary to go beyond that to include thinking on human security that stresses the absence of human needs necessary for sustainable development. Japan therefore promotes human security by strengthening efforts to cope with threats to human lives, livelihoods and dignity such as poverty, environmental degradation, illicit drugs, and transnational organized crime (Government of Japan, 1999). Within Asia, another prospect for co-optation no doubt emerges from demarches by China to co-opt the concept. Expressed as Non-Traditional Security (NTS), the concept appears to underscore changing pattern in China's responses to intra-state conflicts in many parts of the world.

With regard to the USA, Boxer (2003:200), citing the 2000 National Intelligence Estimate of the US, recalls that "infectious diseases are likely to account for more military hospital admissions than injuries received on the battle field, especially when the military is supporting humanitarian or peacekeeping missions."

Apart from general foreign policy initiatives, a realization of the descriptive and analytical power of human security also influences country specific initiatives. In the case of Japan, for instance, Acharya and Acharya (2000) notes that the recognition of the human security concept was directly related to the Asian currency and financial crises that hit East and South- East Asia in July 1997. While having a devastating impact on the economies of the Asian countries, increasing poverty and spreading political instability, the crises gave rise to a new understanding of security, focusing the attention of the Asian people on humans and not on states.

Further to the above, regional groups and intergovernmental organizations appear to accept the concept in their analysis of collective security threats and in devising solutions to them. Within the UN, an attempt to adopt human security is traced to the 1992 Agenda for Peace proposed by Boutros Boutros Ghali. In that document, Ghali stresses the role of the UN "in an integrated approach to human security" as one of the new requisites in peacemaking, peacekeeping and post-conflict management (Tadjbakhsh, 2005:12). Subsequently in the 1999 Millennium Declaration, Kofi Annan's call for human security to encompass economic development, social justice, environmental protection, democratization, disarmament, and respect for human rights and the rule of law appear to have cemented the UN adoption of the concept. This was confirmed by the publication of a report from the UN High-Level Panel on Threats, Challenges and Change entitled A More Secure World: Our Shared Responsibility and the reform agenda proposed by Annan in Towards All Freedom. Both reports emphasized the need to look beyond traditional security concerns and clearly established the human security

In Africa, Hutchful (2008) observes an early attempt at co-optation during the 1991 Conference on Security, Stability, Development and Co-operation in Africa (CSSDCA) held in Kampala. He opines that the Kampala Document's attempt to integrate development with concepts of security and stability was reflected in the statement "the concept of security must be seen in its wholesomeness and totality. It must be taken beyond the traditional definition, which is largely 
military consideration. The security of each country and of the continent must be taken to include the security of the people to live in peace with access to basic necessities of life while fully participating in the affairs of their society freely and exercising their fundamental human rights"(Aderinwanle, 2000:12).

Subsequent to the Kampala document, a more definitive intent of co-optation is evident in Article 6 of the AU Common African Defence and Security Policy which states:

The causes (the high incidence) of intra-state conflict necessitate a new emphasis on human security, based not only on political values, but on social and economic imperatives as well. This newer, multi-dimensional notion of security thus embraces such issues as human rights; the right to participate fully in the process of governance; the right to equal development, as well as the right to have access to resources and the basic necessities of life; the right to protection against poverty; the right to conducive education and health conditions; the right to protection against national disasters, as well as ecological and environmental degradation. At the national level, the aim would be to safeguard the security of individuals, families, communities, and the state/national life, in economic, political and social dimensions. ${ }^{7}$

Within the European Union, the publication of the European Security Strategy in 2003 and 2004 publication of A Human Security Doctrine for Europe: The Barcelona Report of the Study Group on Europe's Security Capabilities, affirmed the co-optation of human security by acknowledging inherent security values in both promoting the rights of nation states and in protecting the rights of individual citizens. The EU has also provided a proposed force planning structure to support these values (Debiel \& Werthes, 2006).

Tadjbakhsh (2005:16) suggests two main reasons for the acceptance of the doctrine by the EU. First, as an outward-looking strategy, Tadjbakhsh notes that the cooptation of human security into EU affairs could reinforce the image of the EU as a successful example of peaceful development based on cooperation, and on core values such as respect for diversity, the rule of law, human rights, democracy and citizen participation. Second, as a defense strategy, a contribution to global human security is perceived as realistic security policy for Europe, given that people lived in places where poverty, violence and lawlessness persisted in providing ingredients for criminal networks with the likely consequence being the importation of hard drugs and weapons into the European Union among others (Kalder, 2004). Coming from the largest contributor to humanitarian and development assistance in the world, the EU's position has been a good boost to co-opting human security.

Again, the analytical utility of human security vis-a-vis post-conflict development appears to have almost strengthened its co-optation. This is because within the context of post conflict countries where infrastructure and people are broken down (socially and psychologically), it is of insignificant value to conceptualize security only in traditional state centric terms. The presumption is that for such societies, other concerns apart from internal violence such as food rationing, are important and could in fact lead to relapses into violence. Human security therefore provides the way to appreciating latent security challenges in post-conflict development. Little wonder that a number of post conflict recovery strategies are often based on human security considerations manifested in reconciliation (at the national and local levels) operating alongside security sector reforms, economic revival and (re)building of socio-political institutions among others. Such efforts at preventing a relapse into violent conflicts is

\footnotetext{
${ }^{7}$ Article 6 of the African Union, Solemn Declaration on a Common African Defence and Security Policy, adopted at the Second Extraordinary Session of the Heads of State and Government of the African Union. Sirte, Libya. 28 February 2004. Accessed from www.african -union.org/news_events
} 
complemented by efforts at creating sustainable livelihoods that promote the policy relevance of human security. This position is affirmed by the 2005 report of the UN Secretary-General on conflict, peace and development in Africa which stresses the need for post-conflict reconstruction in Africa to address the diverse threats to human security in a comprehensive and coherent manner. ${ }^{8}$

\section{Human Security and Security Policy Making in Ghana: Some Reflections}

As a concept, human security is arguably making inroads into security policy globally. Presently, its utility appears more as a complement to the traditional state-centric notion of security and aims at redefining the relevance of people in the conception of security. In Ghana, the implication of this trend will be felt from a number of angles. This is because since independence, emphasis of successive governments has been on national security. It can be reasonably presumed that the demands of nation-building for an independent country, made it essential to accord national security (from the traditional state-centric point of view) a preeminent position in the country's scheme of things for a better part of life after independence. However, it is also fair to suggest that to some extent, successive governments took advantage of the blurred lines between national and regime security to perpetuate their respective regimes, rather than comprehensively safeguard national security in ways that trickled down to the people. Thus, from the shortage of fresh water, to extreme poverty, health pandemics such as guinea worm infestation and environmental challenges, there have been pervasive and critical threats to the vital core of sections of Ghanaian populace since independence. Thus, even in the absence of a comprehensive human security threat assessment, it goes without saying that the country is faced with significant human security challenges. In evaluating performance in terms of security, Hutchful (2007:41) instructively notes that notwithstanding the challenges confronting the country in terms of national security, Ghana still measures much more favourably on national security than on human security.

In the context of the emerging security paradigm, the first area of adaptation is threat perception. Although some of the challenges to human security have continually been addressed under the rubric of development, redefining them under human security (provided they conform to the critical and pervasive criteria) can advance their consideration from a policy making angle. As Quantson (2007:22) aptly points out, it is important "to assess national security threats as the totality of factors that affect the survival, the protection, the safety, the well-being and the contentment of the people. This means that national security policies should be people-centered."

It will therefore be politically incorrect for governments to, for instance, stress the effects or potential harmful effect of statements by political opponents and journalists (such as under the law on causing fear and panic) ${ }^{9}$ while remaining silent on the violation of entire settlements as a result of critical and pervasive shortages of fresh water supplies. For communities which had hitherto been consigned to effects of the guinea worm infestation, among others, the changes in treat perception allows challenges previously considered as normal development issues to be elevated into the domain of security and thus, assume pole position in the national priorities.

Securitization can be a useful tool in this regard. According to Buzan and associates (1997), it is a process by which actors attempt (through speech acts) to move and legitimize issues from

\footnotetext{
${ }^{8}$ United Nations 2005, A/60/182, para. 35.

${ }^{9}$ Section 208 (1) of the Criminal Code of 1960 (Act 29) states that "any person who publishes or reproduces any statement, rumour or report which is likely to cause fear and alarm to the public or disturb the public peace, knowing or having reason to believe that the statement, rumour or report is false is guilty of a misdemeanor."
} 
political to security contexts. Basically, the motive is to attract extraordinary means or attention. In terms of politics, this can be interpreted to also include extraordinary resources. It is worth noting that this strategy is not new to Ghana. In the 1980s, for instance, following a realization of the threat posed by deforestation to the environment, an intense securitization of deforestation was launched on the back of a famous slogan "when the last tree dies, the last man dies." The process contributed immensely to increasing the stock of trees while checking the fast depletion of trees. It is surmised that this process can facilitate the adaptation of national security to emerging trends in human security.

Human security also implies a widening of security actors or their roles. Currently, the Security and Intelligence Act of 1996 and the National Peace Architecture among others identify some of the statutory security actors in the country - from the National Security Council to regional and district security councils. The roles and responsibilities of these bodies in their respective areas of operation must necessarily reflect human security concerns. Further, in addition to the preexisting actors, there is the need for the introduction of other actors with relevant expertise depending on which aspect of human security dominates a particular area. Thus, experts on health, food, environment among others can be co-opted into the various security apparatuses depending on the specific needs of respective areas. In an area such as Tarkwa, in the Western Region of Ghana, where illegal small scale mining (popularly called Galamsey) is one of the main challenges to environmental security, it will be useful to draft environmental security expects into the district security councils. Such decisions must however be preceded by human security threat assessments to ensure that the expertise employed is relevant to the target population.

All in all, the security environment within Ghana is likely to be adapted incrementally in the coming years due to the strides currently being made in the co-optation of human security as a paradigm in security policy globally.

\section{CONCLUSION}

The seamless co-optation of the concept of human security into security policy making has been challenged by issues relating to analytical utility and its relevance in a state-dominated international system. The former, for instance, raises the question of lack of analytical rigor, which on the face of it, appears to suggest that human security creates room for everything to be considered as a threat to security. The paper however observed that the meticulous use of the "critical and pervasive" criteria has the potential to eliminate the wholesale consideration of everything as security. The realist emphasis on the dominance of the state as a challenge to cooptation is also blighted because through history, the sole emphasis on state dominance often tends to benefit regimes rather than the populace. In any case the revelation of human security not as a competitor to national security, but a complement, clears the path of arguments in that regard. It is not surprising, therefore, that there are significant attempts towards co-opting human security in relevant fields of endeavour.

The specific and overwhelming evidence of its influence on foreign policy is sufficient grounds to suggest that it is here to stay. After all, the foreign policies of countries ride on national interest. Thus, by deduction, human security in it various manifestations is at the heart of the national interest of various countries. Human security is also significant on the agenda of international governmental and non-governmental organization not the least of which is the UN. As the world's leading intergovernmental organization, the transition from traditional peacekeeping operations to multidimensional peace support operations is influenced by the necessity of responding to human security rather than merely sticking to national security.

In the specific context of Ghana, it is important to recognize that the developments in human security will influence incremental modifications in security policy and implementation. This will be geared towards reflecting a global trend in security conceptualization. Such 
modifications will most likely be seen in the expansion of threat perceptions to include critical threats to health and environment among others as well as the widening of the roles and responsibilities of security actors. In an era of multiple, complex, multidimensional and interrelated threats such as those pertaining to climate change food sufficiency and diseases, human security offers a paradigm that comprehensively accounts for threats.

\section{REFERENCES}

Acharya, A. and Acharya, A. (2000, November). "Human Security in the Asia Pacific: Puzzle, Panacea or Peril?” [Online]. Available: www.cpdsindia.org. DA: 23rd May 2009.

Aderinwanle, A. (2000). CSSDCA: An African Agenda for Peace and Prosperity, Ibadan: Intec Printers.

Annan, K. (2000). We the People: The Role of the United Nations in the Twenty-first Century. New York: United Nations.

Boxer, B. (2003, Spring). Providing Basic Human Security. The Washington Quarterly 26(2):199207.

Buzan, B. (2004). A Reductionist, Idealistic Notion that Adds Little Analytical Value. Security Dialogue 35(3):369-370.

Buzan, B.; Waever, O. and de Wile, J. (1998). Security: A New Framework for Analysis. Boulder, CO: Lynne Reinner.

Buzan, B. (1983). People, States \& Fear: The National Security Problem in International Relations. Brighton: Wheatsheaf Books.

Buzan, B. (2001). Human Security in International Perspective. In Anthony, M.C., \& Hassan, M.J. (eds). The Asia Pacific in the New Millenium: Political and Security Challenges. Kuala Lumpur: Institute of Strategic and International Studies.

Chen, L. (1995). Human Security: Concepts and Approaches. In Tatsuro Matsumae and Lincoln C. Chen. (eds). Common Security in Asia New Concepts of Human Security. Tokyo: Tokai University Press.

Collier, P. (1998). On Economic Causes of Civil War. Oxford Economic Papers 50(4): 563-573.

Collier, P. (1999) On the Economic Consequences of Civil War. Oxford Economic Papers (51):168-83.

Commission on Human Security (2003). Human Security Now: Final Report. New York: CHS.

Debiel, T. and Werthes S. (2006). Human Security on Foreign Policy Agendas: Changes, Concepts and Cases. Institute for Development and Peace Report 80. Institute for Development and Peace, Duisburg, Germany.

Du Pisani, A. (1992). Security and Peace in a Post-Apartheid Southern Africa. International Affairs Bulletin 16(3): 4-16.

Edson, S. (2001). Human Security: An Extended and Annotated International Bibliography. Cambridge: Centre for History and Economics. 
Fell, R. (2006, September). Is Human Security our Main Concern in the 21st Century? Journal of Security Sector Management 4(3):1-11.

Gamba, V. (1997) Identification of Threats to Contemporary Regional Security and Challenges to Governance African Security Review (6)5 (Online) Available at http://www.iss.co.za/pubs/asr/6No5/Gamba.html DA: 23 ${ }^{\text {rd }}$ May 2009

Government of Japan (1999). Ministry of Foreign Affairs Diplomatic Bluebook 1999. Available at http://www.mofa.go.jp>08/22/01 DA: 23rd May 2009.

Hendricks, C. (2007, June). Human Security in Africa. African Security Review 16 (2): iv-1.

Hutchful, E. (2008). From Military Security to Human Security. In Akokpari J., NdingaMuvumba A., \& Murithi T. (ed) The African Union and Its Institutions. Cape Town: Centre for Conflict Resolution.

Howe, H.M. (2001). Ambiguos Order: Military forces in African State. Boulder, CO: Lynne Rienner.

Kalder, M. (2004, September). A Human Security Doctrine for Europe Paper presented at the Universal Forum of Cultures, Barcelona, Spain (unpublished).

Krause, K.(2007) Towards a Practical Human Security Agenda.(Geneva Centre for the Democratic Control of Armed Forces (DCAF) Policy Paper - No 26). Geneva, Switzerland.

Mack, A. (2004). A Signifier of Shared Values Security Dialogue 35(3): 366-367.

Owen, T. (2004, September). Human Security - Conflict, Critique and Consensus: Colloquium Remarks and a Proposal for a Threshold-Based Definition. Security Dialogue 35(3): 373-387.

Prunier, G. (1995). The Rwandan Crisis: History of Genocide 1959-1994.London: C. Hurst.

Quantson, K. (2007). The Policy and the Practice of National Security in Ghana: The Past, The Present and The Way Forward. In Bluwey, G.K \& Kumado, K. (eds). Ghana in Search of a National Security Policy.Accra:LECIA.

Tadjbakhsh, S. (2005, September). Human Security: Concepts and Implications with an Application to Post-Intervention Challenges in Afghanistan (Online). Available at http://www.ceri-sciencespo.com/publica/etude/etude117 118.pdf DA: 21 ${ }^{\text {st }}$ February 2011

Thomas, C. (1999). Introduction. In Thomas, C. and Wilkin, P. (eds.). Globalisation, Human Security and the African Experience. London: Lynne Rienner.

Thakur R. (1997). From National to Human Security. In Harris, S. and Mack, M. (eds.)AsiaPacific Security: The Economics-Politics Nexus. Sydney, Australia: Allen \& Unwin.

United Nations Development Program (1994). Human Development Report 1994 - New Dimensions of Human Security. New York: Oxford University Press.

United Nations Development Program, (1993). Human Development Report 1993. New York: Oxford University Press.

United Nations (2000). Millennium Report of the Secretary General of the United Nations. Available at http://www.un.org/millennium/sg/report/DA: 23 August 2011 
Waltz, K.N. (1979). Theory of International Politics. London: Addison Wesley.

Wilkin, P. (1999). Human Security and Class in a Global Economy. In Thomas, C. and Wilkin, P. (eds). Globalisation, Human Security and the African Experience. London: Lynne Rienner.

Zgüç, U. (2007). In the Name of Emancipation? Interrogating the Politics of Canada's Human Security Discourse. A Dissertation Submitted in partial fulfillment of the requirements for the degree of Master of Arts Faculty of Arts and Social Sciences. University of New South Wales, UK. 